\title{
Pablo Neruda
}

Tale ved udstillingsåbning 4. december 1992 på Det kongelige Bibliotek Amager

af lektor Poul Rasmussen, Romansk Institut, Københavns Universitet

De billeder vi står iblandt fortæller lidt om personen Pablo Neruda: nogle få situationer på $1 / 50$ sekund af et helt liv fyldt af symboler og kamp.

Defortæller ogsånogetom derammer han havde skabt om sin tilværelse: hans hjem i Santiago og hans hus ved Isla Negra, den sorte ø, som ikke er nogen ø, men navnet på stranden hvor hans ",hus i sandet"

Nogle af dem, ja langt de fleste af disse genstande, selv husene, er symbolske, men den betydning de havde for ham kan man ikke se, den finder man under lås og slå i montrene derhenne, hvor nogle af hans bøger ligger, og på reolerne i bibliotekerne.

Det er i denne poesi hans betydning ligger, det er der rammerne, som vi her står med et lille udvalg af, får liv, et på mange måder eksemplarisk liv, som vi dels kan glæde os over rent æstetisk, dels lære noget af.

Neruda betragter poesien som det daglige brød. Han siger i sine bekendelser: "Jeg har altid hævdet at forfatterens arbejde hverken er mystisk eller magisk, men, i det mindste for digternes vedkommende, et personligt arbejde til gavn for offentligheden. Det poesien mest ligner er et brød, eller en tallerken i keramik, eller et stykke udskåret træ."

Nerudas poesi begynder som så megen anden med bogen om solnedgange og tusmørke: Crepusculario fra 1923, oy slutter med en række Iysende bøger, bl.a. Memorial de Isla Negra, en poetisk selvbiografi. Men han forlod denne verden midt i det kaos og barbari som opstod efter kuppet i 1973, og det afspejles i nogle få, sidste, mørke, aggressive digte.

Som i alle forfatterskaber er der også i Nerudas nogle milepæle. Den første er Veinte poemas de amor y una canción desesperad (Tyve kærlighedsdigte 
og en fortvivlet sang) (1924), en kærlighedssamling, hvor han forlader stilen fra Tusmørkebogen og søger mod en kortere form, en indre harmoni. Det er en bog fuld af fortvivlelse og passion, blandet med naturbilleder fra det sydlige Chile. Kærligheden deles mellem to kvinder „Marisol“ (Solmaria): den smukke pige fra provinsen, med destore mørke øjneog Marisombra (Skyggemaria): studinen fra hovedstaden med grå baskerhue og blide øjne. Det er kærligheden og smerten, lidenskaben og naturen. Neruda undrede sig ofte over at „denne forpinte bog har vist lykkens vej for mange mennesker", han fik i tidens løb masser af breve om den, og mange fortalte om hvordan de havde fundet hinanden på grund af den bog.

På det tidspunkt begynder Neruda at interessere sig for politik, han deltager aktivt på venstrefløjen, og efterhånden blander han politik ind i sin poesi, men der går mange år før det bliver det centrale budskab, vi skal helt frem til den spanske borgerkrig.

Under sit ophold i østen skriver han den første af de to digtsamlinger der bliver en milepæl i den litterære strømning, der i Danmark går under navnet "modernisme“: Residencia en la Tierra (Ophold på jorden). Der er ingen tvivl om at disse samlinger er påvirket af surrealismen, men det er i den spansksprogede udgave; der er ikke tale om automatskrift.

Den første (1925-1931) er en tematisk velkomponeret samling der handler om omgivelserne/ universet kontra jeget: jeget som et centrum, omgivet af et fjendtligt univers, livet som en „død galop“. Digtekunsten, hans poetik beskrives og der er digte om livsmysteriet, om kærligheden, men meget få: af støvede blikke faldet til jorden/ eller af lydløse blade der begraves, sådan er hun nu, hun der før var Iys.

Han vender sig mod de oprindelige ting, de ting der har værdi i sig selv: sten, elfenben, læder, træ, uld, men de omgiver ham som mure i denne epoke af hans liv.

Der er et erindringsafsnit hvor døden og den døde kærlighed er det centrale, en nattesamling og en dagsamling, digte fra østen, hvor begravelserne på floden er hans udsigt: Jeg arbejder om natten, omgivet af by,/ af fiskere, pottemagere og døde der brændes/med safran og frugter, svøbt i skarlagenrød muselin.

Det næstsidste afsnit handler om ensomheden og heri er det fantastiske digtom fragtdamperens spøgelse, derer den menneskelige tid, som konfronteres 
Pablo Neruda (1904-73).

Den chilenske digter Pablo Neruda debuterede i 1917 med et bidrag i dagbladet La Mañana; i 1923 udsendte han sin første digtsamling Crepusculario. Af hans værker kan nævnes Residencia en la Tierra (Ophold på jorden), España en el Corazón (Spanien i hjertet), Canto General (Den store sang), Confieso que he vivido (Jeg bekender, jeg har levet).

1971 modtog han som den tredje latinamerikanske forfatter Nobelprisen i litteratur.

Udstillingen på Det kongelige Bibliotek Amager var arrangeret af Det kongelige Bibliotek og Den chilenske Ambassade og støttet af Initiativgruppen for Dansk Chilensk Kulturforening og Mellemfolkeligt Samvirke.

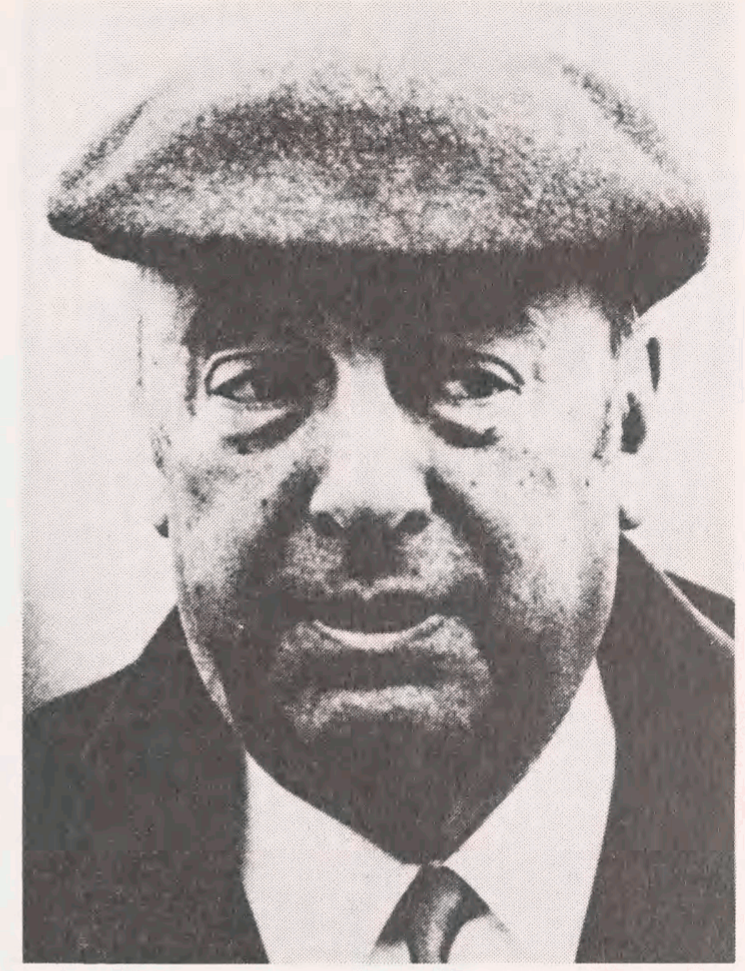

med havet som er den akkumulerede døde tid, og samtidig det nye liv. Vi ser ham til sidst stå på dækket og se ned på havet: Spøgelset ser på havet med sit ansigt uden øjne:/ dagens cirkel, bådens hosten, en fugl / i rummets runde og ensomme ligning. Derefter går han atter ned i båden der er fuld af: stillestående atmosfære og trøstesløst rum.

Det sidste afsnit handler om tidens destruktion af tingene.

I Residencia en la tierra II (1931-1935), som er skrevet i Chile, Argentina og Spanien, når han en større sproglig præcision, temaerne er mange gange de samme: tidens destruktion af livet, kærligheden, sygdommen og døden. Men noget nyt er hans „materielle sange“ der handler om træet, sellerien og vinen, temaer han senere vender tilbage til. Samlingen slutter med et afsnit om tiden "El reloj caido en el mar" (Uret der er faldet i havet), hvor den mekaniske, menneskeskabte tid møder havets døde tid og går i opløsning: Uret som ude på marken lagde sig i mosset / og klappede en hofte med elektrisk form/ løber nu ødelagt og såret under det frygtelige vand / der bølger bankende af centrale strømme. 


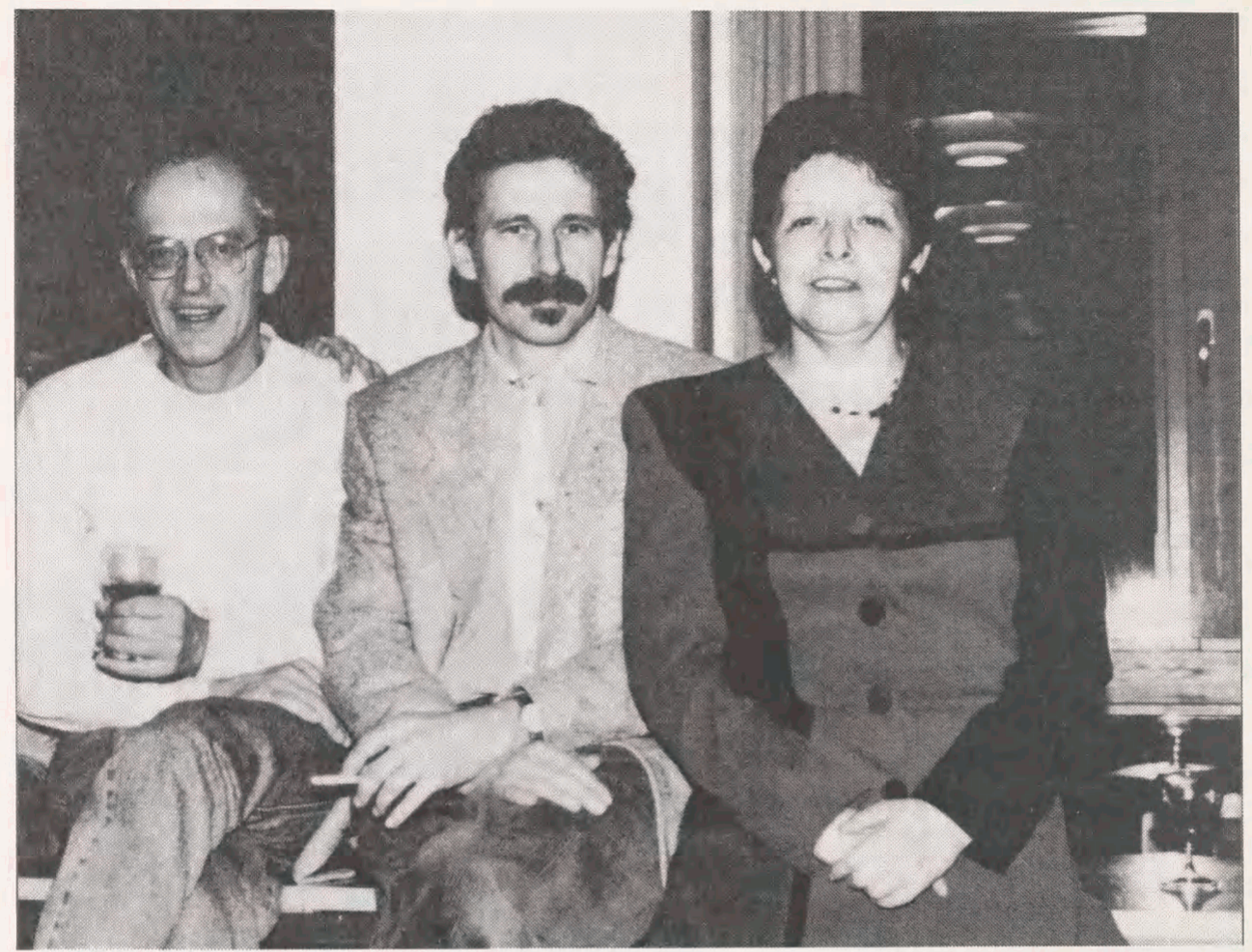

Silvia Rivera, kulturattaché ved Chiles ambassade, ses her sammen med universitetslektor Poul Rasmussen(t.v.) og bibliotekar Filip Regnér, ved udstillingsåbningen 4. december 1992.

I det tredie ophold på jorden, som er skrevet mellem 35 og 45, stiger helt naturligt antallet af digte med politisk indhold: den spanske borgerkrig og 2. verdenskrig: España en el corazón (Spanien i hjertet) og Canto a Stalingrado (Sang til Stalingrad).

Det næste højdepunkt i hans produktion er det enorme epos om Amerika: Canto general, der starter med oprindelsen og livet indtil 1492, beskriver Conquistadorerne, f.eks. Cortes, Befrieme, bl.a. munken Bartolome de las Casas i 1500-tallet og Sandino i 1926, Det forrådte sand med bødlerne og oligarkerne, der alle sammen er forræddere. Og endelig en sang til Amerika. Den anden halvdel handler om Chile og til sidst Neruda selv. Der er mange forskellige afsnit i denne del, f.eks. om ham selv som flygtning, om blomster, floder, skove og selvfølgelig havet: El gran océano (Oceanet).

Efter Canto general har han skrevet mindst 25 digtsamlinger, nogle meget store. 
Der er to smukke kærlighedssamlinger til Matilde Urrutia hans sidste kone: Los versos del capitan (Kaptajnens vers) og 100 Sonetos de amor (100 kærlighedssonetter) der er en meget symbolsk pendant til hans første 20 kærlighedsdigte: det er sonetter, der er hundrede af dem, kærligheden er ikke bukket under, den er tværtimod mangfoldiggjort.

Der er hans tre odebøger: Odas elementales (elementære oder), hvori der er oder til luften, til artiskokken, til en kastanie på jorden, til fattigdommen, dovenskaben, poesien, til pigtråden, sandet og sokkerne, til Paul Robeson og Rimbaud. De slutter med ode til saksen, til tordenvejr i Córdoba, til vals over bølgerne og til den lykkelige rejse. Oder til alle de ting der aldrig, aldrig har fået et digt, de helt simple daglige brugsgenstande.

Han har også skrevet digtsamlinger om Chiles sten, om sit hus i sandet, om fugle og meget andet.

Det sidste højdepunkter hanserindringssamling fra Isla Negra: Memorial de Isla Negra, hvor hele livet gennemgås i den 60-åriges perspektiv. Formen er blevet koncis, de poetiske udtryksmidler er suverænt udnyttet. Den begynder således: Et menneske blev født/ blandt mange/ der fødtes/ jeg levede blandt mange mennesker/der levede/ og dette har ingen historie/men jord. Ogi disse vers er både hans poetiske og hans politiske budskab koncentreret: det starter i ensomhed og slutter i fællesskab.

Hans politiske virksomhed var meget betydningsfuld, dels som diplomat under den spanske borgerkrig, hvor han skaffede mange flygtninge til Chile, dels som senator, hvor han i slutningen af fyrrerne holdt en berømt tale i senatet: Yo acuso (jeg anklager). Den bevirkede at han måtte gå i landflygtighed og først flere år efter vendte han hjem til Chile. Han var kommunisternes præsidentkandidat ved det valg hvor Allende vandt, men han trak sig, så Allende ville få større chancer for at vinde.

Han så klarti 1972-73 hvor det bar hen, og skrev en digtsamling hvori han opfordrede til at myrde Nixon med vers: alle poeter i verden skulle sende vers som kugler mod denne person og det han repræsenterede.

Han døde af kræft umiddelbart efter Pinochets kup, hans huse blev ofre for militærets vandalisme, hans bøger blev brændt, eller stjålet, hans fotografier spredt for alle vinde, og midt i dette kaos ligger Neruda i kisten omgivet af sin elskede Matilde og sine venner. 